\title{
Evaluation of the Association and Rotation of Maize with Legumes, in Direct Sowing in the Democratic Republic of Congo
}

\author{
Gertrude Khonde Pongi ${ }^{1}$, Jean Pierre Tshiabukole Kabongo ${ }^{1 *}$, Amand Kankolongo Mbuya ${ }^{1}$, \\ Stefan Hauser ${ }^{2}$, Antoine Djamba Mumba ${ }^{3}$, Roger Vumilia Kizungu ${ }^{4}$, Constant Nkongolo Kabwe ${ }^{5}$ \\ ${ }^{1}$ Programme National Maïs, INERA, Mvuazi, DRC \\ ${ }^{2}$ IITA, Ibadan, Nigeria \\ ${ }^{3}$ Université Pédagogique Nationale, Kinshasa, DRC \\ ${ }^{4}$ Direction Scientifique, biométrie et expérimentation, Université de Kinshasa, Kinshasa, DRC \\ ${ }^{5}$ Département des Sciences Biologiques, Université Laurentienne, Sudbury, Ontario, Canada \\ Email: *jpkabon2005@gmail.com
}

How to cite this paper: Pongi, G.K., Kabongo, J.P.T., Mbuya, A.K., Hauser, S., Mumba, A.D., Kizungu, R.V. and Kabwe, C.N. (2020) Evaluation of the Association and Rotation of Maize with Legumes, in Direct Sowing in the Democratic Republic of Congo. Open Access Library Journal, 7: e6522.

https://doi.org/10.4236/oalib.1106522

Received: June 13, 2020

Accepted: September 14, 2020

Published: September 17, 2020

Copyright $\odot 2020$ by author(s) and Open Access Library Inc.

This work is licensed under the Creative Commons Attribution International License (CC BY 4.0).

http://creativecommons.org/licenses/by/4.0/

\begin{abstract}
A study was carried out to find, in the intercropping system, the combination for optimizing maize production put into the direct seeding mulch-based cropping systems (DMC). Eight varieties of maize and two legumes were put into intercropping and rotated systems respectively in first and second season, following a factorial system with four replicates. In the second season, maize was sowed on mulch from sole crops and intercrops of first season. The results showed that in the first and second seasons, maize sole crop and maize on maize + cowpea mulch were more productive $\left(2350.19 \mathrm{~kg} \cdot \mathrm{ha}^{-1}\right.$ and 2974.82 $\mathrm{kg} \cdot \mathrm{ha}^{-1}$ respectively) than maize on maize + soybean mulch. But, Mudishi 3-soya and 07SADVE variety on maize + cowpea mulch obtained the greatest benefit for the various association systems (cost/benefit ratio $=4.04$ and $2.01 \mathrm{respec}-$ tively). Maize varieties have doubled, tripled or quadrupled their yields when rotated with cowpea and soybean, and the high yields observed in this study resulted in significant benefits in increasing their ratios whether in combination or in rotation. These new agricultural production techniques could free the farmer from tillage by leaving the cover plants to ensure equivalent work (DMC).
\end{abstract}

\section{Subject Areas \\ Agricultural Science}

\section{Keywords}

Maize, Soybean, Cowpea, Intercropping, Mulch, INERA, DR Congo 


\section{Introduction}

Intercropping was defined as an agricultural practice of growing two or more crops in the same space at the same time. Increasing productivity per unit area can be an important reason for growing two or more crops together [1]. It can be seen as practices application of diversification, competition and facilitation of species in cropping systems [2]. Cereal-legume intercropping plays an important role in food production worldwide. Crop intercropping is commonly practiced because of various advantages such as greater yield stability [3] [4], when one crop fails, the other can still give a reasonable yield [5], a higher efficient land occupation, a high capacity for competition against weeds; legumes can cover their need for atmospheric nitrogen $\left(\mathrm{N}_{2}\right)$ [6] and thus is less competitive for soil nitrogen [4] [7] [8] [9].

In the Democratic Republic of Congo, in general, and in the Province of Central Kongo in particular, the production of legume residues remains low as a result of the export of organic matter out of the field and the practice of waste incineration. According to [10], research that had been carried out for more than 30 years [11] [12] had shown the causes and factors of the physical and chemical degradation of new land; Their findings had suggested a number of locally capable methods of delaying degradation, limiting losses, and even restoring acceptable fertility potential. In the current cropping system, a crop rotation system with the integration of cover crops has also been proposed in addition to the combination of crops, In order to solve the problems of depletion of cultivated soil [13] [14]. Studies conducted in the world have shown that the direct seeding mulch-based cropping system (DMC) ensures a good productivity of the cultivated surfaces and gives many advantages in the soil management [15] [16] [17]. To be successful, these cropping systems must produce high biomass, particularly in the first years of direct seeding.

Although the effects of mulch on the soil are well known [18] [19], but with a low protection, one may wonder what the real impact of this technique on rainfed maize yield and on the evolution of long-term fertility in our fields. Information on the associations and rotations of the different varieties of maize and pulses is very poor and does not allow sufficient information on these crops.

This study aims to acquire knowledge on the response of maize crops in association and rotation with food legumes used as cover crops in order to determine the type of cover to be used in order to better evaluate their effects on maize yield.

\section{Material and Method}

\subsection{Experimental Site, Description and Characterization of Soil}

This study was conducted at the Mvuazi Research Station during the 2011-2012 cropping season. Mvuazi is in the Kongo Central province of DRC with longitude $14^{\circ} 54^{\prime} \mathrm{E}$, latitude $5^{\circ} 21^{\prime} \mathrm{S}$ and altitude $470 \mathrm{~m}$. The soil of Mvuazi belongs to 
the Sudano-Guinean climate zone of the AW4 type [20]. This soil is characterized by low organic matter content and low water holding capacity resulting in low nitrogen availability. This soil valley develops a humiferous horizon $15-25$ $\mathrm{cm}$ thick, black (fresh) or brownish (dry) with a well-pronounced subangular or grumulous structure. And this horizon is often overhauled by crops.

Mean annual temperatures vary between $24^{\circ} \mathrm{C}$ and $30^{\circ} \mathrm{C}$ with rainfall ranging from 800 to $1200 \mathrm{~mm}$. The climatic data recorded during the experimental period are presented in Figure 1.

In this study, soil samples were collected and were analyzed to determine the NPK content and $\mathrm{pH}$. These analyzes were made at the laboratory of Crop $\mathrm{Nu}$ trition Laboratory Services on July 20, 2011, and gave as contents: $0.21 \%$ for nitrogen N, 14 ppm for phosphorus $\mathrm{P}, 105 \mathrm{ppm}$ for potassium $\mathrm{K}$ and a $\mathrm{pH} 5.76$. The selected chemical and physical parameters for soils at experimental site are presented in Table 1.

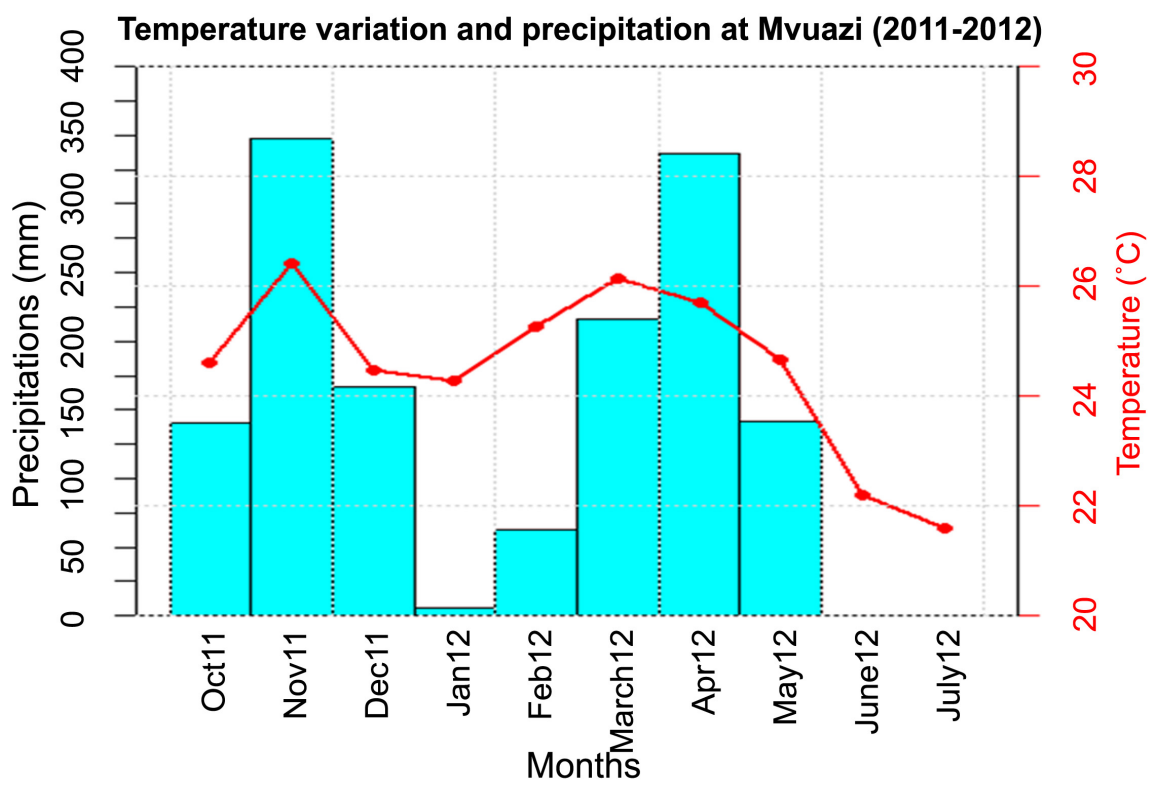

Figure 1. Temperature variation and precipitation amount during the study period.

Table 1. Selected chemical and physical parameters for soils at experimental site.

\begin{tabular}{cccccccccc}
\hline Parameters (unit) & Soil pH & P1 (ppm) & K (ppm) & Ca (ppm) & Mg (ppm) & Mn (ppm) & S (ppm) & Cu (ppm) & B (ppm) \\
\hline Results & 5.76 & 14 & 105 & 1505 & 229 & 55 & 23 & 12.30 & 0.21 \\
Guide Low & 6.00 & 30 & 268 & 1651 & 165 & 100 & 20 & 2.00 & 1.00 \\
Guide high & 7.00 & 100 & 537 & 2064 & 264 & 250 & 200 & 10.00 & 2.00 \\
\hline Parameters (unit) & $\mathrm{Zn} \mathrm{(ppm)}$ & $\mathrm{Na} \mathrm{(ppm)}$ & $\mathrm{Fe}(\mathrm{ppm})$ & $\mathrm{CEC}(\mathrm{meq} / \mathbf{1 0 0 g})$ & OC (meq/100g) & Silt (\%) & Sand (\%) & Clay (\%) & $\mathrm{N}(\%)$ \\
\hline Results & 7.98 & 47 & 194 & 13.76 & 4.07 & 13 & 49 & 39 & 0.21 \\
Guide Low & 4.00 & 0 & 150 & 15.00 & - & 30 & 30 & 20 & 0.20 \\
Guide high & 20.00 & 158 & 350 & 30.00 & - & 50 & 55 & 55 & 0.50 \\
\hline
\end{tabular}




\subsection{Experimental Design and Plant Material}

The trial was conducted under the split-plot design with 4 replications and the main factor consisted to intercropping and rotation treatments and the second factor was maize variety. Eight maize varieties (Mudishi-1, Mudishi-3, 07 SADVE, 08 SADVE1, 09 SADVE-F2, ZM523, VP0538 and Samaru) From CIMMYT/IITA and INERA were sown at a spacing of $1 \mathrm{~m} \times 0.25 \mathrm{~m}$ in sole crop and intercrop with a density of 80,000 plants.ha ${ }^{-1}$, according to [21], in the main plots of $6 \mathrm{~m} \times$ $4 \mathrm{~m}$ of sizes. Soybean (Vuangi variety) and Cowpea (Diamand variety) were simultaneously planted with maize, at a spacing of $0.33 \mathrm{~m} \times 0.055 \mathrm{~m}$ in sole crop and intercrop with a density of 360,000 plants $\cdot \mathrm{ha}^{-1}$. The pure culture for each variety was used as a control treatment. At the end of the first season (2011-2012), all the plots were mown and the residue was used as mulch: corn only, corn + cowpea and corn + soybeans. At the beginning of the second season (2012), corn was planted on a $5 \mathrm{~cm}$ thick mulch [22], without till. So, the experiment was installed in the same plots with a weed mulch plots control.

The parameters observed for this experiment are: maize and legumes yield, number of plants per plot, marketable ears biomass of and unmarketable ears biomass for all maize varieties, edible seed biomass, inedible seed biomass, empty pod biomass for two legume species studied. All of these parameters were observed at the maturity of maize and legume varieties, harvest and post-harvest.

\subsection{Statistical Analyzes}

Data collected were submitted to analysis of variance following the linear model $\left(\operatorname{aov}\left(y \sim\right.\right.$ Trait $\sec ^{\star}$ Trait princ + error (replication/Trait princ)) using agricolae package of R 3.1.3 and least significant difference (LSD) test at $5 \%$ probability level was used to compare the treatment means. An economic analysis was carried out to show the profitability of DMC systems.

\section{Results and Discussion}

\subsection{Intercropping Effect on Number of Plants, Biomass and Maize Yield in First Season}

The number of plants varied from 56.21 for the maize sole crop to 38.6 for intercrop with cowpea. The sole crops of Mudishi1, Mudishi 3 and Samaru proved to be more effective with more than 60 plants per plot. This analysis of variance revealed significant differences $(p<0.05)$ between treatments and varieties (Table 2).

As for the marketable biomass, the difference was significant $(\mathrm{p}<0.05)$ between treatments, but highly significant among varieties $(p<0.001)$, a peculiarity for Mudishi-3 variety which produced more than $73 \%$ of marketable biomass in all treatments. For unmarketable biomass, the difference was not significant between treatments. More losses were observed in sole crop than in intercrop (Table 2). 
Table 2. Intercropping and sole crop effects on the different maize varieties for number of plants, marketable ears biomass, unmarketable ears biomass and yield in first season.

\begin{tabular}{|c|c|c|c|c|c|}
\hline Varieties & Treatments & $\begin{array}{l}\text { Number of } \\
\text { plants }\end{array}$ & $\begin{array}{c}\text { Marketable ears } \\
\text { biomass (\%) }\end{array}$ & $\begin{array}{c}\text { Unmarketable } \\
\text { ears biomass (\%) }\end{array}$ & $\begin{array}{c}\text { Yield } \\
\left(\mathrm{kg} \cdot \mathrm{ha}^{-1}\right)\end{array}$ \\
\hline 07SADVE & Sole crop & $56.00 \mathrm{ab}$ & $68.22 \mathrm{a}$ & $68.72 b$ & $2665.86 a$ \\
\hline 08SADVE1 & Sole crop & $41.75 b$ & $68.51 \mathrm{a}$ & $68.54 \mathrm{~b}$ & $2129.52 \mathrm{a}$ \\
\hline 09SADVEF2 & Sole crop & $54.75 \mathrm{ab}$ & $67.12 \mathrm{ab}$ & $69.91 b$ & $2128.00 \mathrm{a}$ \\
\hline Mudishil & Sole crop & 61.00.a & $70.20 \mathrm{a}$ & $69.32 \mathrm{~b}$ & $2402.40 \mathrm{a}$ \\
\hline Mudishi3 & Sole crop & $61.50 \mathrm{a}$ & $74.77 \mathrm{a}$ & $76.51 \mathrm{a}$ & $2283.62 a$ \\
\hline Samaru & Sole crop & $61.50 \mathrm{a}$ & $72.81 \mathrm{a}$ & $72.26 \mathrm{ab}$ & $2849.44 a$ \\
\hline VP0538 & Sole crop & $54.50 \mathrm{ab}$ & $68.68 \mathrm{a}$ & 73.44ab & $2277.22 \mathrm{a}$ \\
\hline ZM523 & Sole crop & $58.75 a$ & $67.88 \mathrm{a}$ & $72.30 \mathrm{ab}$ & $2065.53 a$ \\
\hline Mean & Sole crop & $56.21 \mathrm{a}$ & $69.77 \mathrm{~b}$ & $71.37 \mathrm{a}$ & $2350.19 a$ \\
\hline 07SADVE & Cowpea & $46.25 a$ & $70.57 a$ & $70.53 \mathrm{ab}$ & $1999.73 a$ \\
\hline 08SADVE1 & Cowpea & $33.75 b$ & $68.56 \mathrm{~b}$ & $62.47 \mathrm{~b}$ & $1298.92 \mathrm{a}$ \\
\hline 09SADVEF2 & Cowpea & $35.5 \mathrm{ab}$ & $68.25 b$ & $69.3 \mathrm{ab}$ & $965.13 \mathrm{a}$ \\
\hline Mudishil & Cowpea & $34.75 \mathrm{ab}$ & $70.63 a$ & $70.9 \mathrm{ab}$ & $753.60 \mathrm{ab}$ \\
\hline Mudishi3 & Cowpea & $46.25 \mathrm{a}$ & $73.87 \mathrm{a}$ & $75.98 \mathrm{a}$ & $1351.04 \mathrm{a}$ \\
\hline Samaru & Cowpea & $46.00 \mathrm{a}$ & $74.13 \mathrm{a}$ & $74.52 \mathrm{a}$ & $2028.88 \mathrm{a}$ \\
\hline VP0538 & Cowpea & $31.50 \mathrm{~b}$ & $73.31 \mathrm{a}$ & $71.67 \mathrm{ab}$ & $1133.73 a$ \\
\hline ZM523 & Cowpea & $35.25 \mathrm{ab}$ & $70.10 \mathrm{a}$ & $68.84 \mathrm{ab}$ & $1212.45 \mathrm{a}$ \\
\hline Mean & Cowpea & $38.65 c$ & $71.17 \mathrm{a}$ & $70.52 a$ & $1342.93 \mathrm{c}$ \\
\hline 07SADVE & Soybean & $52.50 \mathrm{a}$ & $69.33 \mathrm{ab}$ & $69.44 \mathrm{a}$ & $2206.49 a$ \\
\hline 08SADVE1 & Soybean & $41.50 \mathrm{c}$ & $68.20 \mathrm{~b}$ & $63.70 \mathrm{a}$ & $2040.76 a$ \\
\hline 09SADVEF2 & Soybean & $45.50 \mathrm{~b}$ & $68.97 \mathrm{~b}$ & $70.00 \mathrm{a}$ & $1843.63 a$ \\
\hline Mudishi 1 & Soybean & $47.00 \mathrm{~b}$ & $70.64 \mathrm{ab}$ & $72.51 \mathrm{a}$ & $2113.15 a$ \\
\hline Mudishi3 & Soybean & $52.25 \mathrm{a}$ & $75.05 \mathrm{a}$ & $75.92 \mathrm{a}$ & $2291.12 \mathrm{a}$ \\
\hline Samaru & Soybean & $47.50 \mathrm{~b}$ & 71.94ab & $69.13 \mathrm{a}$ & $2113.9 \mathrm{a}$ \\
\hline VP0538 & Soybean & $44.00 \mathrm{bc}$ & $72.64 a$ & $73.63 a$ & $1984.68 \mathrm{a}$ \\
\hline ZM523 & Soybean & $40.00 c$ & $70.57 \mathrm{ab}$ & $72.84 \mathrm{a}$ & $2062.06 a$ \\
\hline Mean & Soybean & $46.28 \mathrm{~b}$ & $70.91 \mathrm{ab}$ & $70.89 \mathrm{a}$ & $2081.97 b$ \\
\hline \multicolumn{2}{|c|}{ Effect of varieties } & $0.01605^{\star}$ & $3.56^{\mathrm{e}-11 * * *}$ & $2.194^{\mathrm{e}-06 * * *}$ & 0.4757 \\
\hline \multicolumn{2}{|c|}{ Effect of treatments } & $1.996^{\mathrm{e}-08 * * *}$ & $0.02226^{*}$ & 0.7206 & $9.842^{\mathrm{e}-05 * \star \star}$ \\
\hline \multicolumn{2}{|c|}{ Effect of varieties $\times$ treatments } & 0.8762 & 0.4624 & 0.6274 & 0.9962 \\
\hline \multicolumn{2}{|c|}{$\mathrm{CV}$} & 18.03 & 2.76 & 5.39 & 32.13 \\
\hline \multicolumn{2}{|c|}{ LSD } & 7.19 & 1.39 & 2.93 & \\
\hline
\end{tabular}

Signification statistique: 0 “***» 0.001 “**” 0.01 “*” 0.05 “†” 0.1 “ns” 1 .

About grain yield, a significant difference was observed $(\mathrm{p}<0.001)$ between treatments (Table 1). Sole crop was greater $\left(2350.2 \mathrm{~kg} \cdot \mathrm{ha}^{-1}\right)$ than the respective 
yield in mixture: $1342.9 \mathrm{~kg} \cdot \mathrm{ha}^{-1}$ for cowpea and $2081.9 \mathrm{~kg} \cdot \mathrm{ha}^{-1}$ for soybeans. Therefore, the highest maize yield was from sole crop of Samaru with 2849.44 $\mathrm{kg} \cdot \mathrm{ha}^{-1}$. The performance results corroborate those of the number of plants and the biomass of the ears. These results was be similar that obtained by [23] in trials at the SUWAN farm in Thailand, where the yield of maize grown in sole crop was $31.9 \%$ higher than maize-soybean. A low density of plants per unit area leads to a decrease in yield [4] [24]. The rate of sowing of each crop in the combination is adjusted below its maximum rate to optimize plant density. If the maximum rate of each crop was used, the yield would not be good due to overpopulation. By reducing the rates of each seedling, the crops have a chance to produce well within intercropping [25]. The challenge is how much can be reduced seeding rates. According to [26] and [27], the spatial arrangement of maize and legumes (intercropping or maize cropping after legume harvesting) does not affect maize yield. A reasonable leaf area index (LAI) is essential to maintain high photosynthesis and yield [28]. Prasad and Brook [29] reported that the increase in corn plant density had a significant effect on LAI in corn-soya intercropping.

\subsection{Intercropping Effect on Number of Plants, Biomass and Legumes Yield in First Season}

Sole crop yield of soybean was higher $\left(1802.23 \mathrm{~kg} \cdot \mathrm{ha}^{-1}\right)$ than that observed in intercrop with maize (809.31 $\left.\mathrm{kg} \cdot \mathrm{ha}^{-1}\right)$ in general, with the association 08SADVE1-soya (932.37 kg.ha ${ }^{-1}$ ) in particular. However, sole crop yield of cowpea produced less $\left(17.82 \mathrm{~kg} \cdot \mathrm{ha}^{-1}\right)$ than the intercrop with maize $\left(48.39 \mathrm{~kg} \cdot \mathrm{ha}^{-1}\right)$, although the highest yield was obtained in the intercrop with Samaru $\left(96.14 \mathrm{~kg} \cdot \mathrm{ha}^{-1}\right)$. Variance analyzes of legume seed yield showed very significant differences $(\mathrm{p}<0.01)$ between varieties and interactions, and highly significant differences $(p<0.001)$ between treatments (Table 2). This reduction in soybean and cowpea yields under intercropping could be due to interspecific competition between the intercrop components for water, light, air and nutrients, and also the aggressive effects maize $\left(\mathrm{C}_{4}\right.$ species) on soybean and cowpea, a $\mathrm{C}_{3}$ species [30] [31]. According to Heibsch et al. [32], crops with $\mathrm{C}_{4}$ photosynthetic pathways have been known to be dominant when intercropped with $\mathrm{C} 3$ species like soybean and cowpea. The shading of legumes by the maize plants (taller) may also have contributed to the reduction of the yields of intercropped soybean and cowpea. Olufajo [33] and Matusso [34] reported that shading by the taller plants in mixture could reduce the photosynthetic rate of the lower growing plants and thereby reduce their yields. As for biomass, highly significant differences $(\mathrm{p}<$ 0.001 ) were observed between treatment for empty pods and edible seeds (Table 3 ). The cowpea monoculture yielded $5.5 \%$ compared to $4.41 \%$ in combination for edible seeds. The soybean monoculture yielded $47.44 \%$ edible seed biomass, compared to the association with $46.13 \%$. Analysis of mean numbers of seedlings and inedible biomass showed no differences between treatments, varieties, and interactions (Table 3). The reduction of yield of the legumes components observed in this study was also reported by other researchers [35]. 
Table 3. Effect of the combination of crops on the number of plants per plot and the biomass of legumes in the first season.

\begin{tabular}{|c|c|c|c|c|c|c|}
\hline Varieties & Treatments & $\begin{array}{c}\text { Number of } \\
\text { plants }\end{array}$ & $\begin{array}{l}\text { Edible seed } \\
\text { biomass (\%) }\end{array}$ & $\begin{array}{c}\text { Inedible seed } \\
\text { biomass (\%) }\end{array}$ & $\begin{array}{c}\text { Empty pod } \\
\text { biomass (\%) }\end{array}$ & $\begin{array}{c}\text { Yield } \\
\left(\mathrm{kg} \cdot \mathrm{ha}^{-1}\right)\end{array}$ \\
\hline Cowpea & Sole crop & 632.75 & $5.50 \mathrm{~b}$ & 11.88 & $24.69 a$ & $17.82 \mathrm{~b}$ \\
\hline Soybean & Sole crop & 554.25 & $47.44 \mathrm{a}$ & 5.03 & $26.80 \mathrm{a}$ & $1802.23 a$ \\
\hline 07SADVE & Cowpea & 525.75 & $12.68 \mathrm{~b}$ & 4.75 & $18.22 \mathrm{a}$ & $76 c$ \\
\hline 08SADVE1 & Cowpea & 555.00 & $3.13 c$ & 9.15 & $30.76 a$ & $15.78 \mathrm{c}$ \\
\hline 09SADVEF2 & Cowpea & 583.75 & $2.09 \mathrm{c}$ & 6.06 & $15.85 \mathrm{a}$ & $39.67 \mathrm{c}$ \\
\hline Mudishil & Cowpea & 541.50 & $3.09 \mathrm{c}$ & 7.003 & $16.51 \mathrm{a}$ & $38.29 c$ \\
\hline Mudishi3 & Cowpea & 577.75 & $0.84 \mathrm{c}$ & 7.84 & $17.54 \mathrm{a}$ & $19.78 \mathrm{c}$ \\
\hline Samaru & Cowpea & 493.75 & $4.09 b c$ & 5.52 & $17.51 \mathrm{a}$ & $96.14 \mathrm{c}$ \\
\hline VP0538 & Cowpea & 489.00 & $5.49 \mathrm{bc}$ & 4.64 & $18.34 \mathrm{a}$ & $33.28 \mathrm{c}$ \\
\hline ZM523 & Cowpea & 545.00 & $3.88 \mathrm{c}$ & 5.07 & $16.44 \mathrm{a}$ & $68.2 \mathrm{c}$ \\
\hline Mean & Cowpea & 538.93 & $4.41 b c$ & 6.25 & $18.89 a$ & $48.39 c$ \\
\hline 07SADVE & Soybean & 468.5 & $46.99 a$ & 6.62 & $30.04 \mathrm{~b}$ & $546.92 \mathrm{~b}$ \\
\hline 08SADVE1 & Soybean & 535.25 & $49.37 \mathrm{a}$ & 5.12 & $27.41 \mathrm{~b}$ & $932.37 \mathrm{a}$ \\
\hline 09SADVEF2 & Soybean & 557.5 & $49.02 \mathrm{a}$ & 4.32 & $28.8 \mathrm{~b}$ & $885.49 a$ \\
\hline Mudishil & Soybean & 489.25 & $45.85 \mathrm{a}$ & 6.38 & $27.17 \mathrm{~b}$ & $859.44 a$ \\
\hline Mudishi3 & Soybean & 617.75 & $44.92 \mathrm{a}$ & 9.11 & $28.19 b$ & $817.77 \mathrm{a}$ \\
\hline Samaru & Soybean & 450 & $41.85 \mathrm{a}$ & 10.53 & $28.28 \mathrm{~b}$ & $718.81 \mathrm{ab}$ \\
\hline VP0538 & Soybean & 497.5 & $45.62 \mathrm{a}$ & 5.74 & $29.64 b$ & $838.61 \mathrm{a}$ \\
\hline ZM523 & Soybean & 579.75 & $45.48 \mathrm{a}$ & 6.52 & $30.34 \mathrm{~b}$ & $875.07 \mathrm{a}$ \\
\hline Mean & Soybean & 524.43 & $46.13 a$ & 6.79 & $28.73 b$ & $809.31 \mathrm{a}$ \\
\hline \multicolumn{2}{|c|}{ Effect of varieties } & 0.2541 & 0.4973 & 0.8859 & 0.819 & $0.0046^{* *}$ \\
\hline \multicolumn{2}{|c|}{ Effect of treatments } & 0.4217 & $<2^{\mathrm{e}-16 \star * *}$ & 0.8342 & $3.936^{\mathrm{e}-05 * * *}$ & $<2.2^{\mathrm{e}-16 * * *}$ \\
\hline \multicolumn{2}{|c|}{ Effect of varieties $\times$ treatments } & 0.9731 & 0.5685 & 0.6336 & 0.521 & $0.0013^{\star *}$ \\
\hline
\end{tabular}

Signification statistique: 0 “***» 0.001 “**»" 0.01 “*” 0.05 “†” 0.1 "ns” 1 .

Matusso [34] reported that the reduction was mainly due to maize shading effects on soybean, which caused the legume component to allocate its photosynthates to vegetative growth and height increasing for competing with taller maize.

\subsection{Mulch Effect on Yield, Number of Plants and Maize Biomass in Second Season}

Mean for the number of plants varied between 58.12 (maize mulch + cowpea) and 60.09 (maize mulch), and for the biomass of salable spikes varied between 49.30 (maize + Cowpea mulch) and 50.77 (maize mulch). For example, maize yield were higher on maize + cowpea mulch $\left(2974.82 \mathrm{~kg} \cdot \mathrm{ha}^{-1}\right)$ followed by maize mulch $\left(2686.77 \mathrm{~kg} \cdot \mathrm{ha}^{-1}\right)$ and maize + soybean mulch $\left(2624.50 \mathrm{~kg} \cdot \mathrm{ha}^{-1}\right)$. Analysis of the variance of all parameters showed no significant differences $(p>0.1)$ be- 
tween varieties, treatments and interactions (Table 4). The observations from the present study indicated that crop rotation and residue management practices can affect maize performance significantly. Edmeades [36] reported similar results from multilocals field experiments in Ghana, which showed that in the

Table 4. Mulch effects on different maize varieties for number of plant, marketable ears biomass, unmarketable ears biomass and yield in second season.

\begin{tabular}{|c|c|c|c|c|c|}
\hline Varieties & Treatments & $\begin{array}{c}\text { Number of } \\
\text { plants }\end{array}$ & $\begin{array}{c}\text { Marketable ears } \\
\text { biomass (\%) }\end{array}$ & $\begin{array}{c}\text { Unmarketable } \\
\text { ears biomass (\%) }\end{array}$ & $\begin{array}{c}\text { Yield } \\
\left(\mathrm{kg} \cdot \mathrm{ha}^{-1}\right)\end{array}$ \\
\hline 07SADVE & maize mulch & 60.75 & 49.81 & 47.41 & 2658.50 \\
\hline 08SADVE1 & maize mulch & 64.75 & 50.07 & 55.74 & 2905.80 \\
\hline 09SADVEF2 & maize mulch & 57.75 & 57.03 & 48.23 & 2586.80 \\
\hline Mudishil & maize mulch & 53.00 & 50.84 & 43.17 & 2467.00 \\
\hline Mudishi3 & maize mulch & 62.50 & 47.99 & 48.11 & 3474.60 \\
\hline Samaru & maize mulch & 59.25 & 54.67 & 50.05 & 2689.00 \\
\hline VP0538 & maize mulch & 61.25 & 48.55 & 61.70 & 2222.40 \\
\hline ZM523 & maize mulch & 61.50 & 47.26 & 47.44 & 2490.10 \\
\hline Mean & maize mulch & 60.09 & 50.77 & 50.23 & 2686.77 \\
\hline 07SADVE & maize + cowpea & 63.50 & 48.90 & 52.44 & 3662.80 \\
\hline 08SADVE1 & maize + cowpea & 55.00 & 47.74 & 47.87 & 2494.40 \\
\hline 09SADVEF2 & maize + cowpea & 60.75 & 43.39 & 48.35 & 3034.10 \\
\hline Mudishi1 & maize + cowpea & 61.50 & 49.85 & 50.41 & 2682.40 \\
\hline Mudishi3 & maize + cowpea & 56.75 & 52.32 & 52.86 & 2897.80 \\
\hline Samaru & maize + cowpea & 55.25 & 55.63 & 53.56 & 3120.20 \\
\hline VP0538 & maize + cowpea & 56.25 & 45.68 & 47.02 & 2847.30 \\
\hline ZM523 & maize + cowpea & 56.00 & 50.93 & 50.45 & 3059.60 \\
\hline Mean & maize + cowpea & 58.12 & 49.30 & 50.37 & 2974.82 \\
\hline 07SADVE & maize + soybean & 60 & 47.54 & 48.54 & 2729.20 \\
\hline 08SADVE1 & maize + soybean & 60.5 & 49.55 & 47.29 & 2548.40 \\
\hline 09SADVEF2 & maize + soybean & 67.5 & 55.46 & 49.27 & 3503.40 \\
\hline Mudishil & maize + soybean & 58 & 53.02 & 48.45 & 2604.80 \\
\hline Mudishi3 & maize + soybean & 56.25 & 53.79 & 46.21 & 2435.30 \\
\hline Samaru & maize + soybean & 55.75 & 49.44 & 54.22 & 2503.10 \\
\hline VP0538 & maize + soybean & 57.25 & 51.9 & 42.42 & 2430.30 \\
\hline ZM523 & maize + soybean & 54 & 44.18 & 49.95 & 2241.50 \\
\hline Mean & maize + soybean & 58.65 & 50.61 & 48.29 & 2624.50 \\
\hline \multicolumn{2}{|c|}{ Effect of varieties } & 0.7018 & 0.4566 & 0.9333 & 0.7053 \\
\hline \multicolumn{2}{|c|}{ Effect of treatments } & 0.6284 & 0.6554 & 0.8318 & 0.2600 \\
\hline \multicolumn{2}{|c|}{ Effect of varieties $\times$ treatments } & 0.6519 & 0.3442 & 0.3797 & 0.7952 \\
\hline
\end{tabular}

Signification statistique: 0 “***” 0.001 “**” 0.01 “*” 0.05 “ $\dagger$ ” 0.1 “ns” 1 . 
absence of fertilizer, maize yields following maize sole crop fell significantly, but that this yield drop could be completely compensated by fertilizers or by a cowpea crop. Cowpeas improve maize yield by the nitrogen they fix and by unspecified improvements in soil conditions. Higher yields under maize-legume rotation would have been expected as legumes are known to fix nitrogen, thereby improving the soil nitrogen economy and enhancing the growth of subsequent crops [37]. The differences in maize response to the different rotations could also be attributed to the differences in biomass additions to the soil. Increased residue returned to the soil generally led to increased yields, whereas complete residue removal was very detrimental to maize growth and yield [38].

\subsection{Variation in Maize Yield in Intercropping and on Mulch}

These variations are of the order of $14.32 \%$ on maize mulch in sole crop, $121.52 \%$ on maize + cowpea mulch and $26.06 \%$ on maize + soybean mulch. Maize was seeded on maize + cowpea mulch doubled, tripled or quadrupled its yield compared to those obtained in intercropping during the first season. Analysis of the variance on the mean variation in yield of maize in combination and on mulch revealed highly significant differences between varieties, treatments and interactions ( $p<0.001)$ (Table 5). These strong variations would be due to the improvement of the fertility of the soil by the effect of crop rotation. Many studies have reported the highly beneficial effects of seed pulses on soil nitrogen content and cereal grain yields [39] [40]. CIPEA's work in Mali showed that the introduction of cowpea into the rotation resulted in a $60 \%$ increase in millet grain yields compared with results obtained in the first year of cultivation [41]. This situation has already been reported by Hardter et al. [42], although the maize-cowpea crop had yields lower than in rotation, continuous sole crop have lower productivities. Carsky et al. [43] showed higher grain yield of cereal following legume than continuous cropping of cereal in the Nigerian savanna. The increases in the cereal yield were attributed to the biologically fixed $\mathrm{N}$ from the legumes. But for such a positive effect to occur, it is expected that the amount of fixed $\mathrm{N}$ returned by the legumes to the soil must be greater than the amount of soil $\mathrm{N}$ in the harvested grain [44] [45].

According to Bandyopadhyay and De [46], this soil fertility can be explained by residual effects on cereals succeeding legumes in the rotation and by the underground transfers of nutrients in the rhizosphere during intercropping. It appears that the use of the cropping system under cover crop (or mulch) increases the maize yield as demonstrated by Scopel [47]. It turned out that most varieties behaved in the same way in each of the treatments. The Mudishil variety increased its yield by more than $250 \%$ when it was planted on cowpea and maize mulch (Table 6). Compared to the results presented in intercropping system, the presence of the mulch significantly influenced the grain yield. This situation shows that even at low doses of mulch ( $5 \mathrm{~cm}$ of residue thickness), a considerable effect can be observed on the behavior of the plants. These results are similar to those reported by Van Asten et al. [22]. These results could be explained that 
sowing under cover crop (or mulch) improves the fertility of the cultivated soils and, in particular, Productivity of the cultivated areas. Mckenney et al. [48], Mary et al. [49], Abiven [50], Schroth et al. [51] showed increased nitrogen availability due to degradation and mineralization of legume mulch compared to bare soil.

Table 5. Intercrops and mulches effects on performance in the first and second seasons.

\begin{tabular}{|c|c|c|c|c|}
\hline \multirow{2}{*}{ Varieties } & \multirow{2}{*}{ Treatments } & \multicolumn{3}{|c|}{ Yield $\left(\mathrm{kg} \cdot \mathrm{ha}^{-1}\right)$} \\
\hline & & Season 1 & Season 2 & Accroissement (\%) \\
\hline 07SADVE & Sole crop & $2665.86 a$ & 2658.50 & $-0.28 \mathrm{~d}$ \\
\hline 08SADVE1 & Sole crop & $2129.52 \mathrm{a}$ & 2905.80 & $36.45 b$ \\
\hline 09SADVEF2 & Sole crop & $2128.00 \mathrm{a}$ & 2586.80 & $21.56 \mathrm{~b}$ \\
\hline Mudishil & Sole crop & $2402.40 \mathrm{a}$ & 2467.00 & $2.69 c$ \\
\hline Mudishi3 & Sole crop & $2283.62 \mathrm{a}$ & 3474.60 & $52.15 a$ \\
\hline Samaru & Sole crop & $2849.44 a$ & 2689.00 & $-5.63 d$ \\
\hline VP0538 & Sole crop & $2277.22 \mathrm{a}$ & 2222.40 & $-2.41 \mathrm{~d}$ \\
\hline ZM523 & Sole crop & $2065.53 a$ & 2490.10 & $20.56 b$ \\
\hline Mean & Sole crop & $2350.19 a$ & 2686.77 & $14.32 \mathrm{c}$ \\
\hline 07SADVE & Cowpea & $1999.73 a$ & 3662.80 & $83.16 \mathrm{c}$ \\
\hline 08SADVE1 & Cowpea & $1298.92 \mathrm{a}$ & 2494.40 & $92.04 \mathrm{c}$ \\
\hline 09SADVEF2 & Cowpea & $965.13 a$ & 3034.10 & $214.37 \mathrm{a}$ \\
\hline Mudishil & Cowpea & $753.60 \mathrm{ab}$ & 2682.40 & $255.94 a$ \\
\hline Mudishi3 & Cowpea & $1351.04 \mathrm{a}$ & 2897.80 & $114.49 b$ \\
\hline Samaru & Cowpea & $2028.88 \mathrm{a}$ & 3120.20 & $53.79 d$ \\
\hline VP0538 & Cowpea & $1133.73 a$ & 2847.30 & $151.14 \mathrm{~b}$ \\
\hline ZM523 & Cowpea & $1212.45 a$ & 3059.60 & $152.35 b$ \\
\hline Mean & Cowpea & $1342.93 c$ & 2974.82 & $121.52 \mathrm{a}$ \\
\hline 07SADVE & Soybean & $2206.49 a$ & 2729.20 & $23.69 b$ \\
\hline 08SADVE1 & Soybean & $2040.76 a$ & 2548.40 & $24.88 b$ \\
\hline 09SADVEF2 & Soybean & $1843.63 a$ & 3503.40 & $90.03 a$ \\
\hline Mudishi1 & Soybean & $2113.15 a$ & 2604.80 & $23.27 b$ \\
\hline Mudishi3 & Soybean & $2291.12 \mathrm{a}$ & 2435.30 & $6.29 \mathrm{~d}$ \\
\hline Samaru & Soybean & $2113.90 \mathrm{a}$ & 2503.10 & $18.41 \mathrm{c}$ \\
\hline VP0538 & Soybean & $1984.68 \mathrm{a}$ & 2430.30 & $22.45 b$ \\
\hline ZM523 & Soybean & $2062.06 \mathrm{a}$ & 2241.50 & $8.70 \mathrm{~d}$ \\
\hline Mean & Soybean & $2081.97 b$ & 2624.50 & $26.06 \mathrm{~b}$ \\
\hline \multicolumn{2}{|c|}{ Effect of varieties } & 0.4757 & 0.7053 & 0.4937 \\
\hline \multicolumn{2}{|c|}{ Effect of treatments } & $9.842^{\mathrm{e}-05 \star \star *}$ & 0.2600 & $1.55^{\mathrm{e}-06 * \star *}$ \\
\hline Effect of vari & $\times$ treatments & 0.9962 & 0.7952 & 0.7580 \\
\hline
\end{tabular}

Signification statistique: 0 “***” 0.001 “**” 0.01 “*” 0.05 “ †” 0.1 “ns” 1 . 
Table 6. Economic analysis of maize varieties in combination with legumes.

\begin{tabular}{|c|c|c|c|c|}
\hline Varieties & Treatments & Gross return (\$) & Net return (\$) & Cost/return ratio (\%) \\
\hline 07SADVE & Cowpea & $3459.53 \mathrm{ab}$ & $2223.66 \mathrm{ab}$ & 2.80 \\
\hline 08SADVE1 & Cowpea & $2191.17 b c$ & $955.30 \mathrm{bc}$ & 1.77 \\
\hline 09SADVEF2 & Cowpea & $1674.65 \mathrm{bc}$ & $438.79 b c$ & 1.36 \\
\hline Mudishil & Cowpea & $1319.82 \mathrm{c}$ & $83.96 \mathrm{c}$ & 1.07 \\
\hline Mudishi3 & Cowpea & $2284.71 b c$ & $1048.84 \mathrm{bc}$ & 1.85 \\
\hline Samaru & Cowpea & $3541.70 \mathrm{bc}$ & $2305.83 \mathrm{ab}$ & 2.87 \\
\hline VPO538 & Cowpea & $1945.02 \mathrm{bc}$ & $709.15 b c$ & 1.57 \\
\hline ZM523 & Cowpea & $2134.42 \mathrm{bc}$ & $898.55 b c$ & 1.73 \\
\hline Mean & Cowpea & $2330.48 \mathrm{ab}$ & $1088.43 \mathrm{ab}$ & 1.88 \\
\hline 07SADVE & Soybean & $4589.01 \mathrm{a}$ & $3307.14 \mathrm{a}$ & 3.58 \\
\hline 08SADVE1 & Soybean & $4955.21 \mathrm{a}$ & $3673.34 \mathrm{a}$ & 3.87 \\
\hline 09SADVEF2 & Soybean & $4548.52 \mathrm{a}$ & $3266.65 a$ & 3.55 \\
\hline Mudishil & Soybean & $4954.32 \mathrm{a}$ & $3672.45 \mathrm{a}$ & 3.86 \\
\hline Mudishi3 & Soybean & $5181.48 \mathrm{a}$ & $3899.61 \mathrm{a}$ & 4.04 \\
\hline Samaru & Soybean & $4721.18 \mathrm{a}$ & $3439.31 \mathrm{a}$ & 3.68 \\
\hline VPO538 & Soybean & $4705.47 \mathrm{a}$ & $3423.60 \mathrm{a}$ & 3.67 \\
\hline ZM523 & Soybean & $4895.21 \mathrm{a}$ & $3613.35 \mathrm{a}$ & 3.82 \\
\hline Mean & Soybean & $4842.89 a$ & $3554.62 a$ & 3.76 \\
\hline 07SADVE & Sole crop & $1333.15 c$ & $120.48 \mathrm{c}$ & 1.10 \\
\hline 08SADVE1 & Sole crop & $865.94 \mathrm{c}$ & $-346.72 c$ & 0.71 \\
\hline 09SADVEF2 & Sole crop & $643.41 \mathrm{c}$ & $-569.25 c$ & 0.53 \\
\hline Mudishil & Sole crop & $502.40 \mathrm{c}$ & $-710.27 c$ & 0.41 \\
\hline Mudishi3 & Sole crop & $900.69 c$ & $-311.97 c$ & 0.74 \\
\hline Samaru & Sole crop & $1352.58 \mathrm{c}$ & $139.92 \mathrm{c}$ & 1.12 \\
\hline VPO538 & Sole crop & $755.81 \mathrm{c}$ & $-456.85 c$ & 0.62 \\
\hline ZM523 & Sole crop & $808.30 \mathrm{c}$ & $-404.37 c$ & 0.67 \\
\hline Mean & Sole crop & $899.77 b$ & $-2551.71 b$ & 0.74 \\
\hline \multicolumn{2}{|c|}{ Effect of varieties } & 0.6241 & 0.6241 & 0.5963 \\
\hline \multicolumn{2}{|c|}{ Effect of treatments } & $<2^{\mathrm{e}-16 * * *}$ & $<2^{\mathrm{e}-16 * * *}$ & $4.834^{e-16}$ \\
\hline \multicolumn{2}{|c|}{ Effect of varieties $\times$ treatments } & 0.9695 & 0.9695 & 0.9665 \\
\hline
\end{tabular}

Signification statistique: 0 “***” 0.001 “**” 0.01 “*” 0.05 “ $\dagger$ ” 0.1 "ns” 1 . Average procurement price per kg of maize $=\$ 0.67$; cowpea $=\$ 1$; soybean $=\$ 1$.

An organic matter and minerals enrichment through residual recycling was studied by Owens and Edwards [52] and Uzoh et al. [53] on maize-soybean-cowpea rotation, highlighting the recycling of carbon and nitrogen through the production of Vegetable biomass of legume. 


\subsection{Economic Analysis of Maize Varieties in a Combination and Rotation System on Legume Mulch}

The economic analysis of different crops indicated gains for maize-cowpea (\$1088.43) and maize-soybean (\$3554.62) intercrops, losses for maize sole crops except for 07SADVE and Samaru varieties for which we observed gains in order of $\$ 121.09$ and $\$ 140.62$ respectively. On the different intercropping systems, the maximum net return were \$USD 3919.12 (Mudishi 3-soya) and minimum were $\$ 712.70$ (VPO538-cowpea). The greatest cost/benefit ratio of the Mudishi 3 -soybean intercrop (4.04) indicates the low investment cost in operating expenses, while highest deficit observed in Mudishi 1 variety sole crop (\$713.82) showing the high investment cost in operating expenses. Analysis of the variance of gross return, benefit, and benefit/cost ratio in intercropping economic analysis revealed highly significant differences $(\mathrm{p}<0.001)$ between treatments (Table 6).

Maize varieties with soybeans in intercropping system produced higher values gross return and net return than maize-cowpea associations and the different sole crop, probably due to yields obtained in each crops. The large benefit produced in the maize/soybean intercrop compared to other systems could probably be the result of the high yield and price of legumes compared to maize [27]. Similar observations were made by Egbe [54] in pigeon pea-sorghum and pigeon pea-maize, and Banik (1996) in wheat-gram, wheat-pea and wheat-lentil intercrops. Njoroge et al. [55] estimated the net profit of coffee associated with food products by subtracting all variable costs from gross profits. Similarly, Egbe [54] had estimated the total profit and the marginal benefit/cost ratio from investment on different farm inputs used in pigeon pea/sorghum intercropping system by computing returns per naira invested. In an innovative, improved intercropping system, named MBILI (kiswahili for "two", and an acronym for "Managing Beneficial Interactions in Legume Intercrops"), also known as a two-by-two staggered arrangement [56], the MBILI system resulted in robust increases in crop yields and net benefits, in comparison with the conventional intercropping system. The MBILI system did not entail larger labour costs and Woomer [57] showed that the MBILI system was profitable across a wide range of smallholders' croplands in western Kenya, and that, when combined with a fertilizer application at a modest rate; the benefit-cost ratio was higher relative to other recommended technologies in the area.

In contrast, analysis of the variance of gross return, benefit, and benefit/cost ratio in mulch crops system revealed no significant differences $(p>0.1)$ between varieties, treatments and interactions (Table 7$)$. On the different mulch cropping systems, maximum net return were \$USD 1234.03 (07SADVE-cowpea) with a cost/benefit ratio of 2.01 and the minimum benefits were \$USD 268.95 (VPO538 sole crop).

Residue production by preceding crop is an important factor in defining the magnitude of rotation benefit conferred to subsequent crop [58]. This is because 
Table 7. Economic analysis of corn varieties on legume mulch.

\begin{tabular}{|c|c|c|c|c|}
\hline Varieties & Treatments & Gross return (\$) & Net return $(\$)$ & Cost/return ratio (\%) \\
\hline 07SADVE & maize + cowpea & 2441.89 & 1227.89 & 2.01 \\
\hline 08SADVE1 & maize + cowpea & 1662.90 & 448.90 & 1.37 \\
\hline 09SADVEF2 & maize + cowpea & 2022.71 & 808.71 & 1.67 \\
\hline Mudishil & maize + cowpea & 1788.24 & 574.24 & 1.47 \\
\hline Mudishi3 & maize + cowpea & 1931.88 & 717.88 & 1.59 \\
\hline Samaru & maize + cowpea & 2080.11 & 866.11 & 1.71 \\
\hline VPO538 & maize + cowpea & 1898.23 & 684.23 & 1.56 \\
\hline ZM523 & maize + cowpea & 2039.74 & 825.74 & 1.68 \\
\hline Mean & maize + cowpea & 1993.13 & 773.06 & 1.63 \\
\hline 07SADVE & maize + soybean & 1819.48 & 605.48 & 1.5 \\
\hline 08SADVE1 & maize + soybean & 1698.90 & 484.90 & 1.4 \\
\hline 09SADVEF2 & maize + soybean & 2335.61 & 1121.61 & 1.92 \\
\hline Mudishil & maize + soybean & 1736.53 & 522.53 & 1.43 \\
\hline Mudishi3 & maize + soybean & 1623.53 & 409.53 & 1.34 \\
\hline Samaru & maize + soybean & 1668.74 & 454.74 & 1.37 \\
\hline VPO538 & maize + soybean & 1620.21 & 406.21 & 1.33 \\
\hline ZM523 & maize + soybean & 1494.33 & 280.33 & 1.23 \\
\hline Mean & maize + soybean & 1758.41 & 538.34 & 1.44 \\
\hline 07SADVE & maize mulch & 1772.34 & 558.34 & 1.46 \\
\hline 08SADVE1 & maize mulch & 1937.19 & 723.19 & 1.6 \\
\hline 09SADVEF2 & maize mulch & 1724.51 & 510.51 & 1.42 \\
\hline Mudishi1 & maize mulch & 1644.65 & 430.65 & 1.35 \\
\hline Mudishi3 & maize mulch & 2316.42 & 1102.42 & 1.91 \\
\hline Samaru & maize mulch & 1792.64 & 578.64 & 1.48 \\
\hline VPO538 & maize mulch & 1481.61 & 267.61 & 1.22 \\
\hline ZM523 & maize mulch & 1660.05 & 446.05 & 1.37 \\
\hline Mean & maize mulch & 1800.13 & 580.06 & 1.48 \\
\hline \multicolumn{2}{|c|}{ Effect of varieties } & 0.7053 & 0.7053 & 0.7053 \\
\hline \multicolumn{2}{|c|}{ Effect of treatments } & 0.2600 & 0.2600 & 0.2600 \\
\hline \multicolumn{2}{|c|}{ Effect of varieties $\times$ treatments } & 0.7952 & 0.7952 & 0.7952 \\
\hline
\end{tabular}

Signification statistique: 0 “***” 0.001 “**” 0.01 “*” 0.05 “ $\dagger$ ” 0.1 "ns” 1. Average procurement price per kg of maize $=\$ 0.67$; cowpea $=\$ 1$; soybean $=\$ 1$.

Legume crop residues contain organic $\mathrm{N}$ and other nutrients, which are released after decomposition by soil microbes for the subsequent crop through mineralization [59]. And the quality of residue is very important in determining mineralization and nutrient release and then yield. Some of the residue parameters include $\mathrm{C} / \mathrm{N}$ ratio, nutrient content etc. Uzoh et al. [53] reported that maize residues contained more carbon and less nitrogen than legumes residues and mineraliza- 
tion and release of nutrients were higher in plots amended with legumes residue as velvet-bean.

\section{Conclusion}

This study was to acquire knowledge on the profitability and response of maize crop in intercrop and rotation with legumes based on DMC to determine the optimum combination of yield grain and total grain biomass. The residual effects of cowpea crops have been shown to have considerably increased maize yield. As for the production of pulses in combination with maize, soybeans were more efficient than cowpeas. All maize varieties each presented a combination that maximized productivity. The varieties 09SADVE F2, Mudishi1, Mudishi3, VPO538 and Zm523 have doubled, tripled or quadrupled their yields when rotated with cowpea. Maize sole crop, which produces poor mulch, resulted in low yields in the second season, resulting in losses of more than $5 \%$. The high yields observed in this study resulted in significant benefits in increasing their ratios whether in combination or in rotation.

\section{Acknowledgements}

We would like to thank the staff of The National Institute of Study and Research Agronomy (INERA) and The International Institute of Tropical Agriculture (IITA) for this financial support.

\section{Conflicts of Interest}

The authors declare no conflicts of interest regarding the publication of this paper.

\section{References}

[1] Hamd Alla, W.A., Shalaby, E.M., Dawood, R.A. and Zohry, A.A. (2014) Effect of Cowpea (Vigna sinensis L.) with Maize (Zea mays L.) Intercropping on Yield and Its Components. International Journal of Biological, Veterinary, Agricultural and Food Engineering, 8, 1170-1176.

[2] Hauggaard-Nielsen, H., Andersen, M.K., Jørnsgaard, B. and Jensen, E.S. (2006) Density and Relative Frequency Effects on Competitive Interactions and Resource Use in Pea-Barley Intercrops. Field Crops Research, 95, 256-267. https://doi.org/10.1016/j.fcr.2005.03.003

[3] Ofori, F. and Stern, W.R. (1987) Cereal-Legume Intercropping Systems. Advances in Agronomy, 41, 41-90. https://doi.org/10.1016/S0065-2113(08)60802-0

[4] Mandal, M.K., Banerjee, M., Banerjee, H., Pathak, A. and Das, R. (2014) Evaluation of Cereal-Legumes Intercropping Systems through Productivity and Competition Ability. Asian Journal of Science and Technology, 5, 233-237.

[5] Steiner, K.G. (1982) Intercropping in Tropical Smallholder Agriculture with Special Reference to West Africa. Schriftenreihe der GT2, N. 137, Eischbon, 303 p.

[6] Hauggaard-Nielsen, H., Ambus, P. and Jensen, E.S. (2001) Evaluating Pea and Barley Cultivars for Complementary in Intercropping at Different Levels of Soil $\mathrm{N}$ Availability. Field Crops Research, 72, 185-196. https://doi.org/10.1016/S0378-4290(01)00176-9 
[7] Sanginga, N. and Woomer, P.I. (2009) Integrated Soil Fertility Management in Africa: Principles, Practices, and Developmental Processes. TSBF-CIAT, Nairobi, $263 \mathrm{p}$.

[8] Trenbath, B.R. (1976) Plant Interactions in Mixed Crop Communities. In: Papendick, R.I., Sanchez, P.A. and Triplett, G.B., Eds., Multiple Cropping, American Society of Agronomy Special Publication, 129-170.

https://doi.org/10.2134/asaspecpub27.c8

[9] Willey, R.W., Natarajan, M., Reddy, M.S., Rao, M.R., Nambiar, P.T.C.M., Kannaiyan, J. and Bhatnagar, V.S. (1983) Intercropping Studies with Annual Crops. In: Nugent, J. and O'Connor, M., Eds., Better Crop for Food, Pitman Co., London, 83-100.

[10] Roose, E. (1984) Impact du défrichement sur la dégradation des sols tropicaux. Machine Agricole Tropicale, 87, 24-36.

[11] Beirnaert, G. (1941) La technique culturale sous 1'Equateur. Publ. INEAC Ser. Techn., $86 \mathrm{p}$.

[12] Jurion, F. and Henry, J. (1967) De l'agriculture itinérante l'agriculture intensifiée. INEAC, Bruxelles, 498 p.

[13] Ilnicki, R.D. and Enache, A.J. (1992) Subterranean Clover Living Mulch: An Alternative Method of Weed Control. Agriculture, Ecosystems \& Environment, 40, 249-264. https://doi.org/10.1016/0167-8809(92)90096-T

[14] Machet, J.M., Laurent, F., Chapot, J.Y., Dore, T. and Dutrout, A. (1997) Maîtrise de l'azote dans les intercultures et les jachères. In INRA Ed., Maîtrise de l'azote dans les agrosystèrnes, Les Colloques No. 83, 271-288.

[15] Capillon, A. and Seguy, L. (2002) Ecosystèmes cultivés et stockage du carbone. Cas des systèmes de culture en semis direct avec couverture végétale. Comptes Rendus de 1 Académie d' Agriculture de France, 88, 63-70.

[16] CIALCA (2008) Rapport d'avancement 4-Bujumbura, Amélioration des moyens de vie basés sur l'agriculture en Afrique Centrale par le biais d'une productivité de systèmes durablement accrue en vue d'améliorer les revenus, la sécurité alimentaire et l'environnement. Réunion de lancement de CIALCA-II, Bujumbura, du 28 au 31 octobre 2008, $28 \mathrm{p}$.

[17] Mucheru-Muna, M., Pypers, P., Mugendi, D., Kung'u, J., Mugwe, J., Merckx, R. and Vanlauwe, B. (2010) A Staggered Maize-Legume Intercrop Arrangement Robustly Increases Crop Yields and Economic Returns in the Highlands of Central Kenya. Field Crops Research, 115, 132-139. https://doi.org/10.1016/j.fcr.2009.10.013

[18] Gilley, J.E., Finkuer, S.C. and Varvel, G.E. (1987) Slope Length and Surface Residue Influences on Runoff and Erosion. Transactions-American Society of Agricultural Engineers, 30, 148. https://doi.org/10.13031/2013.30417

[19] Alberts, E. and Neibling, W.H. (1994) Influence of Crop Residues on Water Erosion. In: Unger, P.W., Ed., Managing Agricultural Residues, Lewis Pub., 20-39.

[20] Köppen, W. (1936) Das geogrphische system der climate. In: Köppen, W. and Geiger, R., Eds., Handbuch der klimatologie, Grebrüder Borntraeger, Berlin, 1-44.

[21] Paliwal, L.R., Granados, G., Violic, A.D., Lafitte, H.R. and Marathee, J.P. (2002) Le maïs en zones tropicales: Amélioration et production. $256 \mathrm{p}$.

[22] Van Asten, P.J.A., Twagirayezu, P. and Gaidashova, S. (2007) Effect of Guatamala Grass (Tripsacum laxum) Mulch Applications on Soil Moisture Conservation and Soil Fertility Status. Proceedings of ISAR National Conference, Kigali, 26-27.

[23] Kasetsart University (1989) Annual Report. Department of Agronomy and National Corn and Sorghum Research Center, Bangkok. 
[24] Jeyakumaran, J. and Seran, T.H. (2007) Studies on Intercropping Capsicum (Capsicum annum L.) with Bushitao (Vigna unguiculata L.). Proceedings of the 6 th Annual Research Session, 18-19 October 2007, 431-440.

[25] Seran, T.H. and Brintha, I. (2010) Review on Maize Based Intercropping. Journal of Agronomy, 9, 135-145. https://doi.org/10.3923/ja.2010.135.145

[26] Adafre, A.N. (2016) Advantages of Maize-Haricot Bean Intercropping over Sole Cropping through Competition Indices at West Badewacho Woreda, Hadiya Zone, SNNPR. Academic Research Journal of Agricultural Science and Research, 4, 1-8.

[27] Khonde, P., Tshiabukole, K., Kankolongo, M., Hauser, S., Djamba, M., Vumilia, K. and Nkongolo, K. (2018) Evaluation of Yield and Competition Indices for Intercropped Eight Maize Varieties, Soybean and Cowpea in the Zone of Savanna of South-West RD Congo. Open Access Library Journal, 5, e3746.

https://doi.org/10.4236/oalib.1103746

[28] Xiaolei, S. and Zhifeng, W. (2002) The Optimal Leaf Area Index for Cucumber Photosynthesis and Production in Plastic Green House. ISHS Acta Horticulturae, 633 (XXVI International Horticultural Congress).

http://www.actahort.org/books/633/633_19.htm

[29] Prasad, R.B. and Brooks, R.M. (2005) Effects of Varying Maize Density on Intercropped Maize and Soybeans in Nepal. Experimental Agriculture, 41, 365-382. https://doi.org/10.1017/S0014479705002693

[30] Egbe, O.M., Alibo, S.E. and Nwueze, I. (2010) Evaluation of Some Extra-Early- and Early-Maturing Cowpea Varieties for Intercropping with Maize in Southern Guinea Savanna of Nigeria. Agriculture and Biology Journal of North America, 1, 845-858. https://doi.org/10.5251/abjna.2010.1.5.845.858

[31] Muoneke, C.O., Ogwuche, M.A.O. and Kalu, B.A. (2007) Effect of Maize Planting Density on the Performance of Maize/Soybean Intercropping System in a Guinea Savannah Agro-Ecosystem. African Journal of Agricultural Research, 2, 667-677.

[32] Hiebsch, C., Tetio-Kegho, F. and Chirembo, F.P. (1995) Plant Density and Soybean Maturity in a Soybean-Maize Intercrop. Agronomy Journal, 87, 965-970. https://doi.org/10.2134/agronj1995.00021962008700050032x

[33] Olufajo, O.O., Ogungbile, A.O. and Ahmed, B. (1997) On-Farm Testing of Variety and NPK Fertilization for Maize-Cowpea Mixture in the Nigeria Savanna. In: Sedgo, T. and Oueuedraogo, M., Eds., Technology Options for Sustainable Agriculture in Sub-Saharan Africa, Publication of the Semi-Arid Food Grain Research and Development Agency (SAFGRAD) of the Scientific, Technical and Research Commission of OAU, Oueuedraogo, 235-246.

[34] Matusso, J.M.M. (2014) Effects of Maize (Zea mays L.)-Soybean (Glycine max (L.) Merrill) Intercropping Patterns on Yields and Soil Properties in Two Contrasting Sites of Embu and Meru Counties, Kenya. Thesis, School of Agriculture and Enterprise Development, Kenyatta University, Nairobi.

https://doi.org/10.5897/AJAR2013.7178

[35] Alhassan, G.A., Kalu, B.A. and Egbe, O.M. (2012) Influence of Planting Densities on the Performance of Intercropped Bamabra Groundnut with Cowpea in Makurdi, Benue State, Nigeria. International Journal of Development and Sustainability, 1, $1-20$.

[36] Edmeades, G.O. (1990) Significant Accomplishments of Ghana Grains Development Project during Phase I, 1979-1983. 10th Ann. Maize and Coxpea Workshop of the Ghana Grains Dev. Proj., Kumasi, 20-23.

[37] Cheruiyot, E.K., Mumera, L.M., Nakhone, L.N. and Mwonga, S.M. (2003) Effect of 
Legume-Managed Fallow on Weeds and Soil Nitrogen in Following Maize (Zea mays L.) and Wheat (Triticum aestivum L.) Crops in the Rift Valley Highlands of Kenya. Australian Journal of Experimental Agriculture, 43, 597-604. https://doi.org/10.1071/EA02033

[38] Adiku, S.G.K., Jones, J.W., Kumaga, F.K. and Tonyigah, A. (2009) Effects of Crop Rotation and Fallow Residue Management on Maize Growth, Yield and Soil Carbon in a Savannah-Forest Transition Zone of Ghana. Journal of Agriculture Science, 147, 313-322. https://doi.org/10.1017/S002185960900851X

[39] De, R., Rao, Y.Y. and Ali, W. (1983) Grain and Fodder Legumes as Preceding Crops Affecting the Yield and N Economy in Rice. Journal of Agricultural Science (Cambridge), 101, 463-466. https://doi.org/10.1017/S0021859600037825

[40] Kumar Rao, J.V.D.K., Dart, P.J. and Sastry, P.V.S.S. (1983) Residual Effect of Pigeon Pea (Cajanus cajan) on Yield and Nitrogen Response of Maize. Experimental Agriculture, 19, 137-141. https://doi.org/10.1017/S0014479700022572

[41] CIPEA (1984) Rapport Annuel du CIPEA 1983. Addis-Abeba (Ethiopie).

[42] Hardter, R., Horst, W.J., Schmidt, G. and Frey, E. (1991) Yields and Land Use Efficiency of Maize-Cowpea Crop Rotations in Comparison to Mixed and Monocropping on an Alfisol in Northern Ghana. Journal of Agronomy and Crop Science, 166, 326-337. https://doi.org/10.1111/j.1439-037X.1991.tb00922.x

[43] Carsky, R.J., Abaidoo, R., Dashiell, K.E. and Sanginga, N. (1997) Effect of Soybean on Subsequent Maize Grain Yield in Guinea Savanna of West Africa. African Crop Science Journal, 5, 31-39. https://doi.org/10.4314/acsj.v5i1.27868

[44] Giller, K.E. and Wilson, K.J. (1991) Nitrogen Fixation in Tropical Cropping Systems. CAB International, Wallingford, 167-237.

[45] Yusuf, A.A., Iwuafor, E.N.O., Abaidoo, R.C., Olufajo, O.O. and Sanginga, N. (2009) Grain Legume Rotation Benefits to Maize in the Northern Guinea Savanna of Nigeria: Fixed-Nitrogen versus Other Rotation Effects. Nutrient Cycling in Agroecosystems, 84, 129-139. https://doi.org/10.1007/s10705-008-9232-9

[46] Bandyopandhyay, S.K. and De, R. (1986) N Relationship in a Legume-Non Legume Association Grown in an Intercropping System. Fertilizer Research, 10, 73-82. https://doi.org/10.1007/BF01073906

[47] Scopel, E. (1994) Le semis direct avec paillis de résidus dans la région de V. Carranza au Mexique: Intérêt de cette technique pour améliorer l'alimentation hydrique du maïs pluvial en zones à pluviométrie irrégulière. $\mathrm{PhD}$, Institut National Agronomique Paris-Grignon, Paris, 334 p.

[48] McKenney, D.J., Wang, S.W., Drury, C.F. and Findlay, W.I. (1993) Denitrification and Mineralization in Soil Amended with Legumes, Grass and Corn Residues. Soil Science Society of American Journal, 57, 1013-1020. https://doi.org/10.2136/sssaj1993.03615995005700040022x

[49] Mary, B., Recous, S., Darwis, D. and Robin, D. (1996) Interactions between Decomposition of Plant Residues and Nitrogen Cycling in Soil. Plant and Soil, 181, 71-82. https://doi.org/10.1007/BF00011294

[50] Abiven, S. (2001) Effet de la qualité et de la localisation initial dans le sol sur la décomposition de résidus de culture. DEA Paris, INAA P-G, Paris VI: 41 p.

[51] Schroth, G., Salazar, E. and Da Silva, Jr. J.P. (2001) Soil Nitrogen Mineralization under Tree Crops and Legume Cover Crop in Multi-Strata Agroforestry in Central Amazonia: Spatial and Temporal Patterns. Experimental Agricultural, 37, 253-267. https://doi.org/10.1017/S0014479701002058 
[52] Owens, L.B. and Edwards, W.M. (1993) Tillage Studies with a Corn-Soybean Rotation: Surface Runoff Chemistry. Soil Science Society of American Journal, 57, 1055-1060. https://doi.org/10.2136/sssaj1993.03615995005700040029x

[53] Uzoh, I.M., Igwe, C.A., Okebalama, C.B. and Balalola, O.O. (2019) Legume-Maize Rotation Effect on Maize Productivity and Soil Fertility Parameters under Selected Agronomic Practices in a Sandy Loam Soil. Scientific Reports, 9, Article No. 8539. https://doi.org/10.1038/s41598-019-43679-5

[54] Egbe, O.M. (2005) Evaluation of Some Agronomic Potential of Pigeonpea Genotypes for Intercropping with Maize and Sorghum in Southern Guinea Savanna. PhD Thesis, University of Agriculture, Makurdi.

[55] Njoroge, J.M., Waithaka, K. and Chweya, J.A. (1993) Effects of Intercropping Young Plants of the Compact Arabica Coffee Hybrid Cultivar Ruiru 11 with Potatoes, Tomatoes, Beans and Maize on Coffee Yields and Economic Returns in Kenya. Experimental Agriculture, 29, 373-377. https://doi.org/10.1017/S0014479700020937

[56] Tungani, J.O., Mukhwana, E. and Woomer, P.L. (2002) MBILI Is Number 1: A Handbook for Innovative Maize-Legume Intercropping. SACRED Africa, Bungoma.

[57] Woomer, P.L. (2007) Costs and Returns of Soil Fertility Management Options in Western Kenya. In: Bationo, A., Waswa, B., Kihara, J. and Kimetu, J., Eds., Advances in Integrated Soil Fertility Management in Sub-Saharan Africa: Challenges and Opportunities, Springer, Berlin, 881-890.

https://doi.org/10.1007/978-1-4020-5760-1_84

[58] Seymour, M., Kirkegaard, J.A., Peoples, M.B., White, P.F. and French, R.J. (2012) Break-Crop Benefits to Wheat in Western Australia-Insights from over Three Decades of Research. Crop and Pasture Science, 63, 1-16.

https://doi.org/10.1071/CP11320

[59] Chu, G., Shen, Q. and Cao, J. (2004) Nitrogen Fixation and N Transfer from Peanut to Rice Cultivated in Aerobic Soil in an Intercropping System and Its Effect on Soil N Fertility. Plant and Soil, 263, 17-27. https://doi.org/10.1023/B:PLSO.0000047722.49160.9e 